$$
\begin{array}{lllll}
\text { 矢 } & \text { 栄***国 } & \text { 井 } & \text { 蔵** } \\
\text { 吉 岡 } & \text { 隆***.梅 } & \text { 山 英 } & \text { 美*** }
\end{array}
$$

\section{1. 緒言}

炭菜質成分と酸化チタンを主成分とする高チタン鉣涬 を粉挽混合しビッチ，タールなどのバインダーで結合さ せて団鉱を成形し，高温で塩素を作用させて還元塩素化 し四塩化チタニウムを作る反応は古くから研究されまた 現在工業的にる行われている。しかし反応速度を測定し 装置の設計に利用できる形にまとめようとする試るはま だ報告されていないようである。筆者らはこの反応の化 学工学的解明を行い簡単な基碄実験から実際の装置の設 計資料を求めその運転条件を知ることを試みた。本報告 では原料の酸化チタンが反応温度で固体であるのに反応 により生成する四塩化チタニウムは気体であるため反応 の進行に伴い重量が減少することを利用し，密閉型の熱 天科を用いて反応による重量の減少速度を測定しこれか ら化学反応速度定数, フッシュ内拡散係数，ガス境膜係 数を決定した。さらにこの数値を用いて単一の球形団捈 の反応所要時間を計算し困示した。これを用いれば移動 層, 固定層および流動層塩菜化装置につきその生産能力 と反応条件，装置の大きさなどの関係は物質収支をとる ことにより計算することができるがこれ関しては後日 報告する予定である。

\section{2. 実験}

(2・1）試 料 所定の粒径のビッチコークスと高 チタン筑涬を一定の比率で混合し，15\% 可溶性泟粉水溶 液をかずかに加えて $250 \mathrm{~kg} / \mathrm{cm}^{2}$ の压力で直径 $6.5 \mathrm{~mm}$ の円简形に成形し，これを $600^{\circ} \mathrm{C} て ゙ 2$ 時間窒素気流中で 加熱し水分を完全に除去し，冷却後密栓保存する。高子 タン鉱㳯の分析值を Table 1 亿示した。

（2－2）装是およひ操作 Fig. 1 のような密閉型熱 天科を使用した。上記試料を Fig. 2 のサンブルホルダ 一に充填し，石英反応管内につるし，窒素気流を通しな がら加熱し、一定の温度に達した後塩索気流に切替える。 I 分ことに反応による重量減少を石英スブリングの縮み から読む。かくして得た実騟值の1例を示すと Fig. 3 のとおりである8。

- 昭和 34 年 1 月 31 日受理

** 束大工学部応用化学科化学工学教室

***德山曹達株式会社

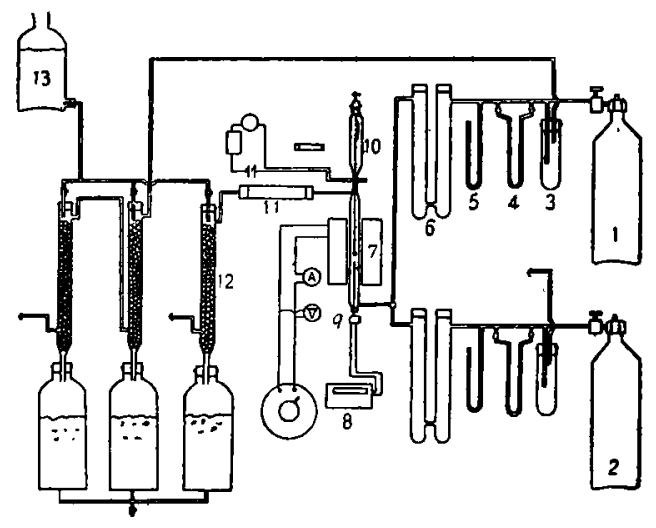
1) $\mathrm{Cl}_{2}$ bomb
2) $\mathrm{N}_{2}$ bomb
3) constant-pressure holder 4) flow-meter
5) manometor 6) $\mathrm{CaCl}_{2}$ 7) electric furnace
8) pyrometer
9) thermo-couple
10) spring of quartz 11) $\mathrm{CaCl}_{2}$
12) tower packed with rashig ring 13) $\mathrm{NaOH}$ aq.

Fig. 1 Schematic diagram of experimental apparatus

Table 1

Chemical composition of Titan slag

\begin{tabular}{lr} 
component & weight \% \\
\hline $\mathrm{TiO}_{2}$ & 75.58 \\
$\mathrm{FeO}_{\mathrm{Fe}}$ & 5.87 \\
$\mathrm{Fl}_{2} \mathrm{O}_{3}$ & 3.20 \\
$\mathrm{Al}_{2} \mathrm{O}_{3}$ & 7.60 \\
$\mathrm{MgO}$ & 6.16 \\
$\mathrm{CaO}$ & - \\
$\mathrm{SiO}_{2}$ & 3.0 \\
Total & 101.41
\end{tabular}

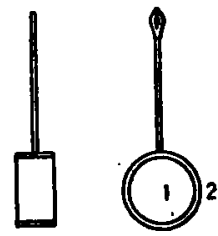

1) sample

2) sample holder made of quartz

Fig. 2

Sample holder

\section{3. 理論式の㫫出}

理論式の導出にあたって反応の進行状況(中途の状況)

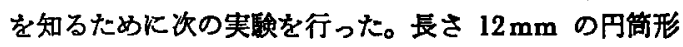
試料を長さ $12 \mathrm{~mm}$ のホルダーに詰め, 下記の条件で掹 菜化を行い, 10 分間で塩素ガスの導入を止め窒菜で置換 し冷却後試料をとり出した。このときの全重量減少は

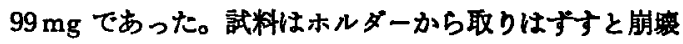
するので，ホルダーに入れたまま表面を針でけずり視察 


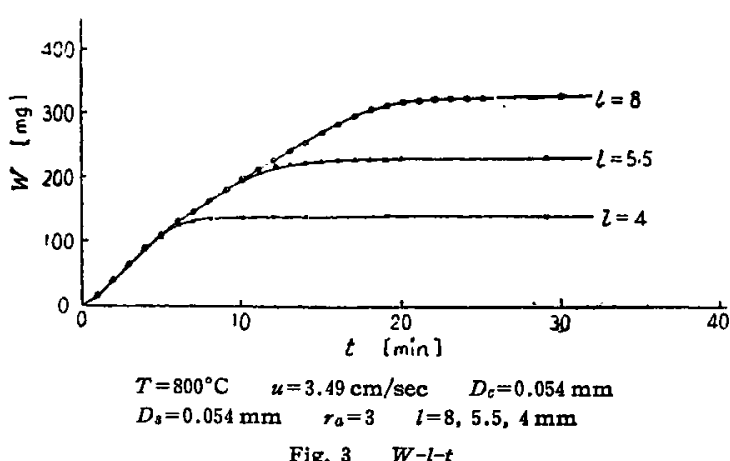

した。

\begin{tabular}{|c|c|}
\hline 反店温度 & $800^{\circ} \mathrm{C}$ \\
\hline 蓝案流 速 & $3.49 \mathrm{~cm} / \mathrm{sec}$ \\
\hline 缊 策 浱 度 & $0.744 \cdot 10^{-3} \mathrm{~g} / \mathrm{cc}$ \\
\hline 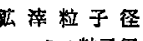 & $0.054 \mathrm{~mm}$ \\
\hline コークス粒子径 & $0.054 \mathrm{~mm}$ \\
\hline 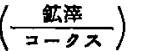 & 3 (霆量比) \\
\hline
\end{tabular}

[A] 表面から $1 \mathrm{~mm}$ の深さの所までは脆弱であっ た。

[B] $1 \mathrm{~mm}$ から $2 \mathrm{~mm}$ の部分は相当に硬いがけずる ことは容易であった。

[C] $2 \mathrm{~mm}$ から $3 \mathrm{~mm}$ の部分は硬くやきしまってけ ずることはほとんど不可能であった。これより 内側の部分は同様に硬かった。

これから [B] を境として, 外側の [A] は反応完了層, 内側は末反応部分と区分できよ。一方他の実験から試 料の長さが $12 \mathrm{~mm}$ で反応条件が上記と同じ場合，反応

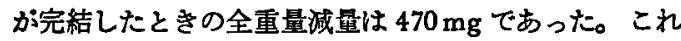
から $99 \mathrm{mg}$ の重量減少は表面から $1.26 \mathrm{~mm}$ の層まて反 応が終ったことに相当する。な抑反応後の試料の表面を 䫒徽䍌でみるとガラスウールをゆるくつめたよらな状態 である。 $r_{a}=3$ の場合反応が完了したときの重量の減少 事が 70\%にも達することから想像されるよ5に極めて 多孔性である。孔の大きさは10〜50ミクロンであった。 上の実験に基づ、て Fig. 4 のような模型を考え，さ らに次の 4 つの仮定"゙たたて以下論をすすめる。

仮 定 1. 試料は均一でどの部分も反応対して同一 条件にある。

仮 定 2. 反応帯での反応は塩素に関して1次として 表現できる。

仮定 3. 短い時間では定常状熊と考える。

仮定 4. 反応帯の厚みを見掛け上零と考党て反応面

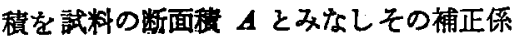
数をてとする。

かくすればガス境膜，フッシュ内の塩素移動速度お゙よ

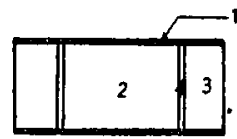

1) silica tube

2) non-reacted part

3) reacted ash

d) reaction-zone

Fig. 4

Model of sample

び反応带での塩素消費速度は次の諸式で表現する ことができる。

$$
\begin{aligned}
& \text { ガス境膜 } \frac{d m}{d t}=k_{f} \cdot A \cdot\left(C_{1}-C_{2}{ }^{\prime}\right) \\
& \text { アッシュ } \frac{d m}{d t}=\frac{C_{1}{ }^{\prime}-C_{s}}{x} \cdot A \cdot D_{v} \\
& \text { 化学反応 } \frac{d m}{d t}=\gamma k_{0} \cdot A \cdot\left(C_{s}-C^{*}\right)
\end{aligned}
$$

ただし $C_{1}, C_{1}{ }^{\prime} ， C_{8}, C^{*}$ はとれぞれガス本流中，試料表 面，反応带，平衡打ける塩素浱度である。(1)，(2)， (3) 式上り

$$
\frac{d m}{d t}=\frac{A}{\frac{1}{k_{f}}+\frac{x}{D_{v o}}+\frac{1}{\gamma k_{0}}} \cdot\left(C_{1}-C^{*}\right)
$$

塩素移動量 $m$, フッシュ層厚又 $x$ は反応に伴了試料の 重量減少Wで固換できる。比例倸数をすおよびると拉 くと

$$
\begin{gathered}
m=\delta W \\
x=b^{-1} W
\end{gathered}
$$

（4）に（5)，(6) を代入すると

$$
\frac{d W}{d t}=\frac{a}{\beta+W}
$$

ただし

$$
\begin{aligned}
& \alpha=\left\{\delta^{-1} \cdot A \cdot b \cdot\left(C_{1}-C^{*}\right)\right\} D_{v 0} \\
& \beta=b \cdot D_{v 0} \cdot\left(\frac{1}{k_{f}}+\frac{1}{\tau k_{0}}\right) \\
& \frac{\beta}{a}=\left\{\frac{\delta}{A\left(C_{1}-C^{*}\right)}\right\}\left(\frac{1}{k_{f}}+\frac{1}{\gamma k_{\mathrm{o}}}\right)
\end{aligned}
$$

$\delta \cdot A \cdot b \cdot C_{1}$ は简単に計算あるいは実測して知ることがて きる。 $C^{*}$ は反応に伴う自由エネルギー变化から計算て きるが本反応では零である。以上から $\alpha, \beta / \alpha$ を実駼似 上り求め机ば (8), (10) 式を用いて $D_{p e t}\left(k_{f}^{-1}+\gamma^{-1} k_{s}^{-1}\right)$ を計算できる。

4. （7）式と実験值， $\alpha$ および $\beta / \alpha$ を求める方法 (7) 式加

$$
\left(\frac{d W}{d t}\right)^{-1}=\frac{\beta}{a}+\frac{1}{a} W
$$

したがって Fig. 3 のことき実测值 ( $t$ 対 $W$ )より 
$\left(W\right.$ 対 $\left.\left(\frac{d W}{d t}\right)^{-1}\right)$ を求め点緅すると直線になるはずで ある。その直線の勾配和よび程軸と交わる点より，aと $\beta / \alpha$ を求めることができる*。次に (7)'式で $(d W / d t)^{-1}$ は $W$ のみの函数で未反応量には然関係である。試料の 面㭼 $A$ は同じで長ざいろいろ変えてその他の条件は 同しとして反応させたときは，この一連の実験の $\left((d W / d t)^{-1}\right.$ 対 $\left.W\right)$ 点緅するとすべての点は1 本の直 線の上にのるはずである。試料の長さ $l$ が $3,4,5.5,6$, 8、10 $\mathrm{mm}$ のものについて塩素化を行ったとき実験值は Fig. 5 のごとくであった。同じ $W=100 \mathrm{mg}$ の場合を 考えても $l=10 \mathrm{~mm}$ のものでは未反応量は $l=4 \mathrm{~mm} の$ ものの約 7 倍であったが $(d W / d t)^{-1}$ は両者とも 0.0475 $\mathrm{min} / \mathrm{mg}$ で一致している。Fig. 5 で反応の初期と反応 末期は直線上にないがこれはつぎのことく考えられる。

（1）反応初期 ガス切替直後の混乱拉よび反応带 の生成期。この時期は窒素がスを塩素ガスに切替え，反 応を開始した直後であるため両ガスの直換にある時間を 必要とすること拈よび Fig. 4 の4すなわち反応帯が形 成されるまでの時間は（7）式の適用ができないことの二 つの理由で直楾上に実験值がのらない。

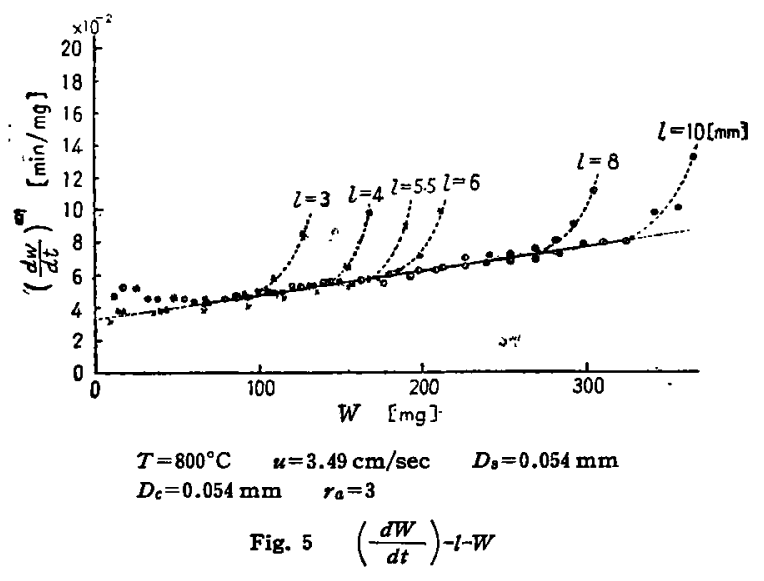

Table 2 (Reaction-temperature)$\left(D_{v 8}, D_{v f}, X\right.$ and $\left.B\right)$

\begin{tabular}{lllllll}
$T\left[{ }^{\circ} \mathrm{C}\right]$ & 650 & 700 & 750 & 800 & 850 & 900 \\
\hline$D_{v s}\left[\mathrm{~cm}^{2} / \mathrm{sec}\right]$ & 0.265 & 0.358 & 0.363 & 0.421 & 0.429 & 0.524 \\
$X[-]$ & 0.478 & 0.610 & 0.635 & 0.695 & 0.724 & 0.699 \\
$D_{v f}\left[\mathrm{~cm}^{2} / \mathrm{sec}\right]$ & 0.327 & 0.375 & 0.415 & 0.4575 & 0.499 & 0.544 \\
$X \cdot D_{v f}$ & 0.157 & 0.229 & 0.264 & 0.318 & 0.361 & 0.381 \\
$B$ & 1.69 & 1.56 & 1.37 & 1.33 & 1.19 & 1.37
\end{tabular}

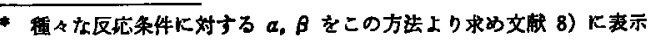
してある。
（2）反応末期, 反応帯消減期 反応が進行しで末 反応部分が忹とんとなくなると Fig.4の2つの反応帯 は遂に接触し，以後反応は反応帯の消隇を伴って行われ る。したがって 3 節理論式導出の仮定 4 における補正俰 数 $r$ を定とする仮定は成立しないのでこの期間は実験 値が理論線にのらない。

\section{5. アッシュ内拡散定数 $\boldsymbol{D}_{v \varepsilon}$}

フッシュ内を塩素が拡散する通路断面積と試料断面皘 の比ををとすれば

$$
D_{v \varepsilon}=e D_{v f}
$$

と考えられる。反応が完了したときの試料の重量减少率 を $X$ とすれば $\varepsilon$ は $X$ に比例すると考えられるから

$$
D_{v \mathrm{~s}}=B \cdot X \cdot D_{v f}
$$

$D_{\mathrm{v} f}$ はガス中の拡散定数で 2 成分系については Gilliland $の$ 式 $^{2}$

$$
D_{v f}=\frac{0.0043 T^{3 / 2} \sqrt{M_{1}^{-1}+M_{2}^{-2}}}{\left(V_{1}^{1 / 3}+V_{2}^{1 / 3}\right)^{2} P}
$$

多成分系の場合はWilke の近似的方法30

$$
\left(D_{v f}\right)_{1}=\frac{1-y_{1}}{y_{2} / D_{1.2}+y_{2} / D_{1.3}+\cdots \cdots}
$$

を組合わせて計算できる。たたし $\boldsymbol{y}$ は多成分系成 分ガスのモル分率である。本実験で主反応は次式 であらわされる。

$$
\begin{aligned}
& \mathrm{TiO}_{2}+s \mathrm{C}+2 \mathrm{Cl}_{2} \\
& \quad \longrightarrow \mathrm{TiCl}_{4}+q \mathrm{CO}_{2}+p \mathrm{CO}
\end{aligned}
$$

フッシュ内ガス組成は実测できないので C, CO, $\mathrm{CO}_{2}$ は平衡状態にあるとすれば $\mathrm{CO}$ と $\mathrm{CO}_{2}$ の 濃度の比は自由エネルギー变化から計算できる。 問題は $\mathrm{Cl}_{2}$ であるが $\mathrm{TiCl}_{4}, \mathrm{CO}_{2}, \mathrm{CO}$ のモル分 率の比が定まれば $\mathrm{Cl}_{2}$ 濃度は相当広く变化させて む（13），(14）式から計算した $D_{v f}$ はほえど変 らない。 $X$ は実験により求まる。 $D_{\text {v } は}$ は 3 節に述 べた方法で知ることができる。以上の数値を Table 2 に示した。Table 2 の実験では反応温度を 変化させているので $X, D_{\text {vf }}$ の両方が变化してい るがつぎ反応温度 $800^{\circ} \mathrm{C}$ とし鉱㳯とコークス の混合比のみ変化させて実験を行い， $D_{v}$ を求め た。この場合は温度が一定であるから $D_{v f}$ は一定 でXのみが变化する。この結果を Fig. 6 に示し た。（12）式の B を知るために Table 2 拈よび

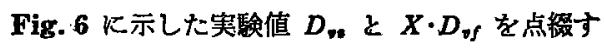
ると Fig. 7 のよ になる。これがら $B=1.42$ と おける。

$$
\therefore D_{v s}=1.42 \cdot X \cdot D_{v f}
$$

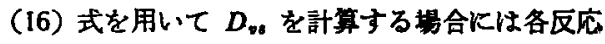




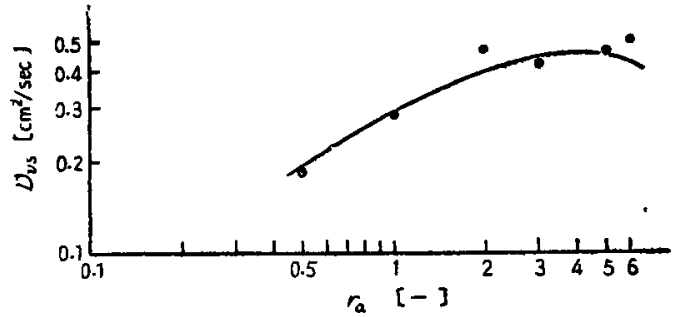

$T=800^{\circ} \mathrm{C} \quad u=3.49 \mathrm{~cm} / \mathrm{sec} \quad D_{c}=0.054 \mathrm{~mm}$ $D_{8}=0.054 \mathrm{~mm} \quad r_{a}=0.5 \sim 6$

Fig. 6 The relation between mixing ratio $r_{a}$ and $D_{v s}$

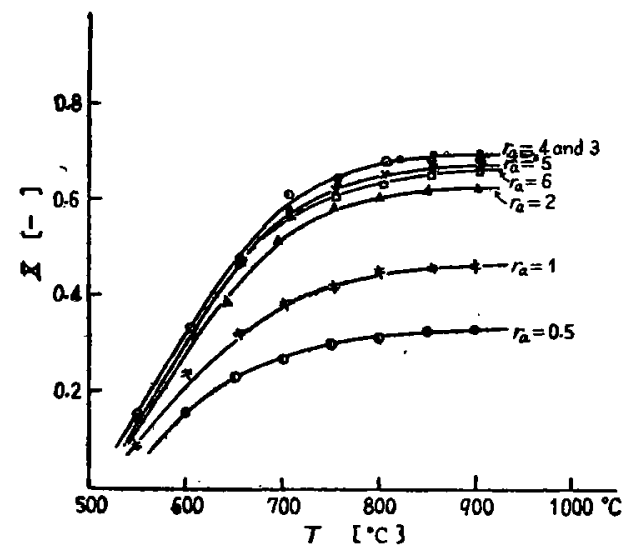

$T=550 \sim 900^{\circ} \mathrm{C} \quad u=3.49 \mathrm{~cm} / \mathrm{sec} \quad D_{c}=0.054 \mathrm{~mm}$ $D_{\mathrm{g}}=0.054 \mathrm{~mm} \quad r_{\mathrm{c}}=0.5 \sim 6$.

Fig. $8 \quad X-r_{a}-T$

条件に対する $D_{v f}$ および $X$ が必要となる。 $D_{v f}$ は Table 2 の値を使用すればよいが $X$ は反応温度のみでは なく混合比によってるかわる。混合比 0.5 6, 温度 550 $\sim 900^{\circ} \mathrm{C}$ の範围で実測した $X$ の值を Fig. 8 に示した。

\section{6. $\left(k_{f}^{-1}+\gamma^{-1} k_{c}^{-1}\right)^{-1}=K$}

4 節の方法で (7) 式と実験值から $\alpha, \beta / \alpha$ を求めると (10) 式から $K$ を求めることができる。 $\ln K$ と $T^{-1}$ を プロットすると Fig. 9 の I， II となる。 $620^{\circ} \mathrm{C}$ 付近で 折線となるのはこの温度でガス境膜の抵抗と化学反応の 抵抗について律速段階が变るためと思われる。常識的に は高温ではガス境膜律速と考えられる。Fig. 9 には $D_{\text {v。 }}$ も同様にプロットした。同図中 I，II，吕の勾配からフル レニウスの式により活性化エネルギーを求める。

$$
\begin{array}{lll}
\text { I } & E_{A \mathrm{I}}=24.4 & \mathrm{kcal} / \mathrm{mol} \\
\text { II } & E_{A \mathrm{I}}=5.40 \quad " & " \\
\text { II } & E_{A \mathrm{II}}=4.53 \quad "
\end{array}
$$

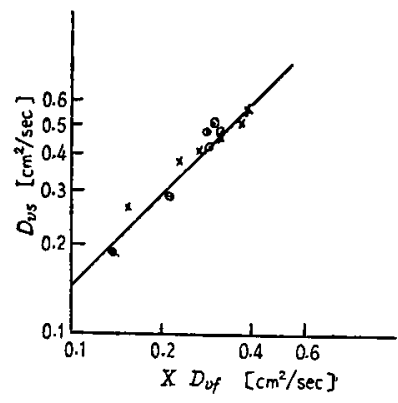

$$
\begin{array}{cccc}
u=3.49 \mathrm{~cm} / \mathrm{sec} & D_{\varepsilon}=0.054 \mathrm{~mm} & D_{s}=0.054 \mathrm{~mm} \\
\times \cdots \cdots T & =650 \sim 900^{\circ} \mathrm{C} \quad r_{a}=3 \\
\odot \cdots \cdots T & =800^{\circ} \mathrm{C} \quad r_{a}=0.5 \sim 6
\end{array}
$$

Fig. $7 \quad D_{v g}-X D_{v f}$

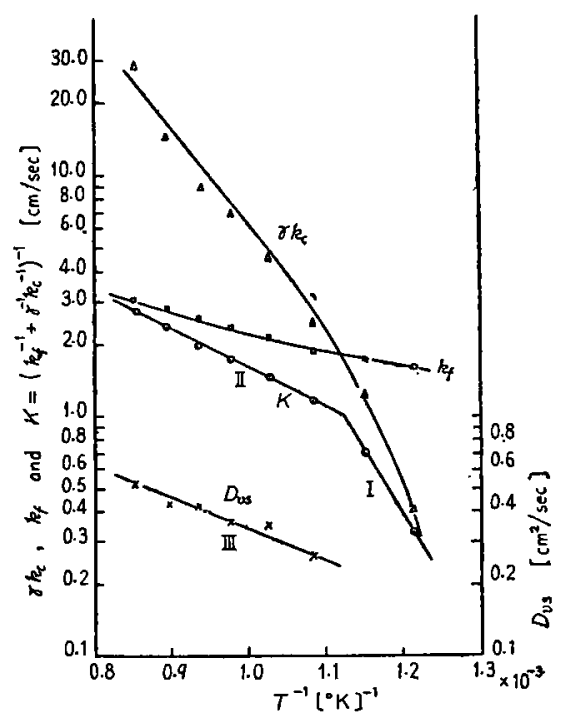

$T=550 \sim 900^{\circ} \mathrm{C} \quad u=3.49 \mathrm{~cm} / \mathrm{sec} \quad D_{c}=0.054 \mathrm{~mm}$ $D_{s}=0.054 \mathrm{~mm} \quad r_{a}=3$

Fig. $9 \quad T^{-1}-\left(r k_{c}, k_{f}, K \& D_{v s}\right)$

$E_{A \mathrm{I}} \fallingdotseq E_{A \mathrm{II}}$ であることからも $620^{\circ} \mathrm{C}$ 以上ではガス境膜 律速，以下で化学反応律速であるとしてよいであろう。

\section{7. ガス境膜物犋移動係数 $\boldsymbol{k}_{\boldsymbol{f}}$}

本実験の実験值から求まるのは $D_{v s}$ と $\left(k_{f}^{-1}+r^{-1} k_{c}{ }^{-1}\right)$ のみであるから $r k_{c}$ を知るためには $k_{f}$ を他の箺験式あ るいは理論式から本実験とは独立に求めなけ机ばならな い。利用し5ると考えられる式はつきの諸式である。

(1) Pohlhausen の平板の式

(2) Froessling の単一球の式5)

(3) Ranz \& Marshall の単一球の式 ${ }^{6)}$

本実験の実験条件を考虑して Froessling の式を用い る。 


$$
\frac{k_{f} D_{p} \xi_{f}}{D_{v f}}=2.0+0.552\left(\frac{\rho D_{p} u}{\mu}\right)^{1 / 2}\left(\frac{\mu}{\rho D_{v f}}\right)^{1 / 3}
$$

$\boldsymbol{\xi}_{\boldsymbol{f}}$ は境膜中の反応に咸係しない成分の平均のモル分率 である。相互抁散系でしかも反応原采 $\left(\mathrm{Cl}_{2}\right)$ のモル数と 生成系 $\left(\mathrm{TiCl}_{4}+\mathrm{CO}+\mathrm{CO}_{2}\right)$ のモル数が等しい場合には $\boldsymbol{\xi}_{f}=1$ である。本反応では丽密には反応原系と生成系の モル数は等しくない。また試料が円筒形であるために形 状俰数の影裂るある。これらの補正を含めて $\xi_{f}$ の代り に皇考学る。

$$
\frac{k_{f} D_{p} \xi}{D_{\text {of }}}=2.0+0.552\left(\frac{\rho D_{p} u}{\mu}\right)^{1 / 2}\left(\frac{\mu}{\rho D_{v f}}\right)^{1 / 3}
$$

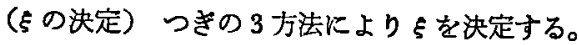

[ 1 ] 塩秉流速のみを変えた一連の実験を行い $K$ を 求める。つきに 5 を仮定して (18) 式から $k_{f}$ を計算し $K$ から $r k_{a}$ を計算する。 $r k_{c}$ は塩素流速に無閣係な量で あるから $r k_{\epsilon}$ が塩素流速の変化に影響されないような をもって正しい值とする。

[2] Fig. 9 で高温ではガス境膜律速であるから $K$ $\fallingdotseq k_{f}$ としてよい。上に求めた 高温に拉ける $K$ との一致を調ベて $\xi$ の值が妥当かどう がを確める。

[3] Fig.9 の折楾 I では反応律速と考えられるの で $K \fallingdotseq \gamma k$ 。とみなせる。折線 I を延長し高温に和ける $\gamma k_{\text {。 }}$ を推定し上に求めた $\xi$ を用いて $K$ から算出した $\gamma k_{\mathrm{c}}$ との一致を調べる。［1]の方法では Fig. 10 より 0.80 とすることができる。[2]，[3]についてはTable 3 に示した。以上の事実から $k_{f}$ の計算には $\xi=0.80$ を 用いて次式を使用する。

$$
k_{f}=\frac{D_{v f}}{D_{p}}\left\{2.5+0.69\left(\frac{\rho D_{p} u}{\mu}\right)^{1 / 2}\left(\frac{\mu}{\rho D_{v f}}\right)^{1 / 3}\right\}
$$

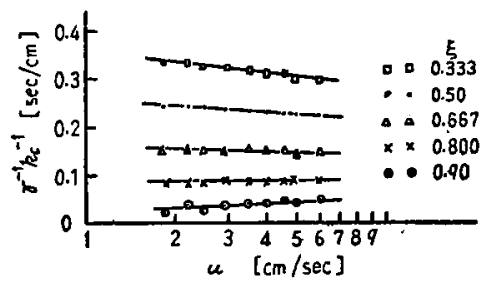

$T=800^{\circ} \mathrm{C} \quad u=1.82 \sim 5.95 \mathrm{~cm} / \mathrm{sec} \quad D_{\epsilon}=0.054 \mathrm{~mm}$ $D_{d}=0.054 \mathrm{~mm} \quad r_{a}=3$

Fig. $10 \quad\left(r k_{c}\right)^{-1}-u$

Table $3 \quad r k_{e}$ and $k_{f}$ at $900^{\circ} \mathrm{C}$

\begin{tabular}{lcc} 
& $\begin{array}{c}\text { Calculated } \\
(\xi=0.8)\end{array}$ & $\begin{array}{c}\text { Supposed } \\
\text { from Fig. 9 }\end{array}$ \\
\hline$r k_{c}$ & $30.0[\mathrm{~cm} / \mathrm{sec}]$ & -1 \\
$k_{f}$ & $3.00[\mathrm{~cm} / \mathrm{sec}]$ & 30.0 \\
& & 2.75
\end{tabular}

\section{8. 化学反话速度定数 $r \boldsymbol{k}$}

（19）式から $k_{f}$ を知れば $K=\left(k_{f}^{-1}+r^{-1} k_{0}^{-1}\right)^{-1}$ から $r k_{\varepsilon}$ は值らに計算できる。 $r k_{c}$ は円筒形試料の断面楼 $\boldsymbol{A}$ を反応面䆅とした化学反応速度定数である。実際の反応 はある厚みをるった反応带で行われる。反応速度はこの 厚みによっても变るし反応带中のピッチュークス，高チ タン鉣涬の粒径および混合比によってむ変化する。反応 帯厚み，括よびこれら粒子の諸性質を表現する項として 先に述べたような $r$ 補正項を普通の化学反応速度定数 $k_{c}$ に加えた。 $r$ は温度の他に反応帯中のコークス粒子の

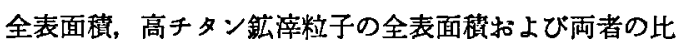
によりかわると考えられるから

$$
r k_{c}=f\left(T \cdot \frac{A_{c}}{A_{s}} \cdot A_{c} \text { or } A_{s}\right)
$$

ただし $A_{c}, A_{8}$ はそれぞれコークスおよび高チタン鉱㳯 粒子のうち反応帯中に含まれているものの全表面䅡であ る。（20）式を求めるために以下 4 系列の実驗を行い, $r k_{c}$ を言算した。

[ i ] 混合比 $r_{a}$ のみを $(0.5 \sim 6)$ の範囲で变化させ 反応温度 $800^{\circ} \mathrm{C}$, 塩素流速 $3.49 \mathrm{~cm} / \mathrm{sec}, D_{e}, D$, と炕 $0.054 \mathrm{~mm}_{0}$ 実験結果は整理するとつきのことくなる。

$$
\begin{array}{ll}
A_{c} / A_{\mathrm{s}} \leqq 0.63 & r k_{\mathrm{c}}=1.70\left(A_{\mathrm{o}} / A_{\mathrm{o}}\right)^{1.38} \\
A_{\mathrm{c}} / A_{\mathrm{s}}>0.63 & r k_{\mathrm{c}}=6.70\left(A_{\mathrm{o}} / A_{\mathrm{s}}\right)^{-0.61}
\end{array}
$$

[ii] コークス粒子径と鉱涬粒子径は等しく, 両者と も $0.27 \sim 0.054 \mathrm{~mm}$ の範囲で変化させる。 $r_{a}=3$ で他の 条件は [i]に同じ。

$$
\gamma k_{c}=1.60 D_{p}^{-1.25}
$$

[iii] 鉣涬粒子径は $0.067 \mathrm{~mm}$ で定としコークス径 のみ $0.27 \sim 0.054 \mathrm{~mm}$ の籍围で变化。

$$
\gamma k_{c}=1.60 D_{c}^{-1.35}
$$

[iv] コークス粒子径は $0.067 \mathrm{~mm}$ で一定とし捈涬径 のみ $0.27 〜 0.054 \mathrm{~mm}$ の籁囲で変化。

$$
r k_{\varepsilon}=0.87 D s^{-0.74}
$$

（21）（25）式をとめて（20）式の形とすると

$$
r k_{c}=\frac{0.16}{D_{p m} 1.35}\left(\frac{0.627 A_{\varepsilon}}{A_{c}}\right)^{n}
$$

ただし $A_{c} / A_{s} \leqq 0.63$ のとき $n=-1.38$

$$
A_{\mathrm{c}} / A_{\mathrm{s}}>0.63 \text { のとき } n=0.61
$$

反応温度 $800^{\circ} \mathrm{C}$ の場合である。 $D_{p m}$ はコークス粒子径 と高キタン鉣涬粒子径が等しくない場合の小さい方の粒 子径である。以上の実験値と（26）式の計算值を Fig. 11 に示した。

\section{9. 単一球の反応完結所要時间12 $\theta_{0}$}

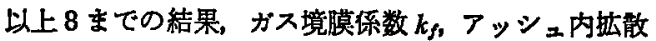
保数 $D_{v e n}$ 化学反応速度定数 $r k_{\mathrm{a}}$ を知ることができた。 


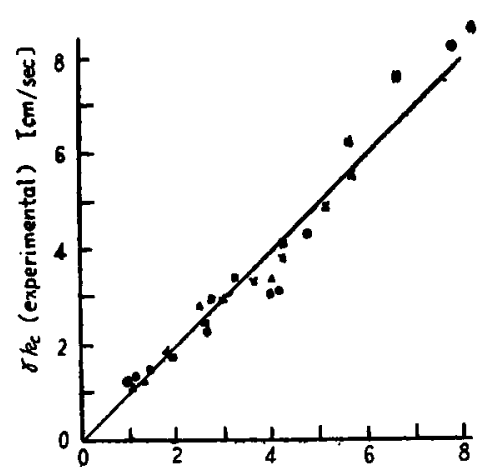

$\delta k_{c}($ Calculated $)=\frac{0.16}{0_{0 . m}^{1.35}}\left(\frac{0.627 A_{s}}{A_{c}}\right)^{n}$

$$
\begin{gathered}
n: A_{c} / A_{s}>0.627 \\
n=0.61 \\
A_{c} / A_{s} \leqq 0.627 \\
n=-1.38
\end{gathered}
$$

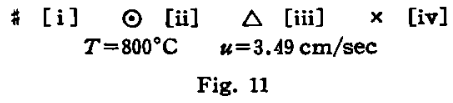

これらを使用して本節では装置設計の基礎となる「単一 球が全表面積を塩素気流にばくろしているときの反応完 結所要時間 $\theta_{0}$ 」を算出する。 $\theta_{0}$ を求める式としてはす でに (27)，(28) 式が理論的に導かれている”。

$$
\begin{aligned}
\theta_{0} & =\frac{D}{2 \alpha^{\prime}\left(C_{1}-C^{*}\right) \bar{k}} \\
\text { ただ } \quad \frac{1}{\bar{k}} & =\frac{1}{r k_{0}}+\frac{D}{12 D_{v z}}+\frac{1}{3 k_{f}}
\end{aligned}
$$

$D$ はュークスと鉱㳯をパインダーで結合させて球形飞 成形した試料の直径である。（27）式を用いれば任意の 反応条件に対する $\theta_{0}$ を計算できる。 $r k_{\theta}, D_{v e}, k_{f}$ は 8 節 まで求めた諸式を利用すればよい。計算例を Fig. 12 に示した。ただし反応の末期には円简形試料のための （7）式が成立しなくなると同样に，球状の場合む（27）, （28）式を導いた仮定が成立しなくなるので（27）式の与 える $\theta_{0}$ は緟密に反応が完結する時間ではなくはとんと 全部が反応する時間といらできである。

\section{0. 姞 語}

高チタン鉱漳の還元塩素化装直を設計するに必要な基 礎データーとして塩素のガス境膜保数、フッシュ内拡散 定数，化学反応速度定数を熱天秤を用いた基碟実験によ り決定した。すなわち塩素のガス境膜係数の計算には （19）式を用い，フッシュ内の拡散定数は Table 1 の組 成の高チタン箯涬を原料とする場合には（16）式を使用 することができる。化学反応速度定数は試料の性質すな わちコークスと鉱㳯の混合比扣よび各粒径と反応温度の 函数であるが本報告では反応温度 $800^{\circ} \mathrm{C}$ のときの試料

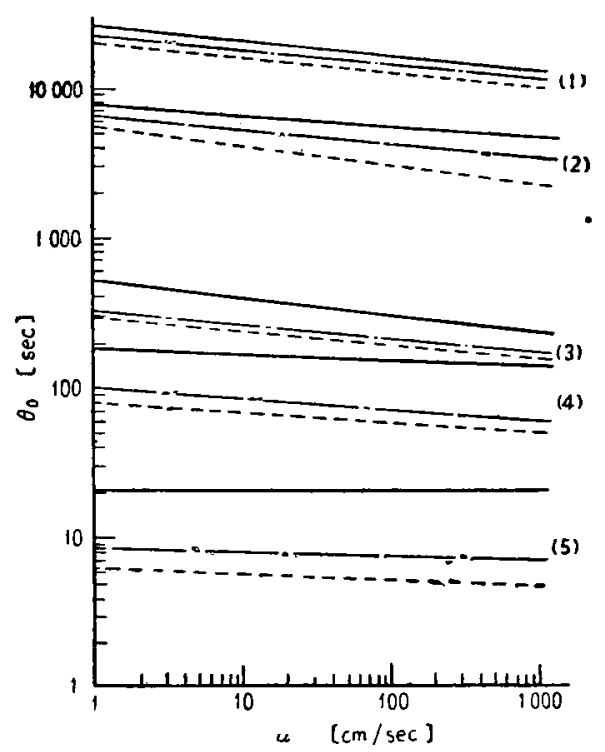

$$
\begin{aligned}
& \text { (1) } D=10 \mathrm{~cm} \quad \text { (2) } D=5 \mathrm{~cm} \quad \text { (3) } D=1 \mathrm{~cm} \\
& \text { (4) } D=0.5 \mathrm{~cm} \quad \text { (5) } D=0.1 \mathrm{~cm}
\end{aligned}
$$

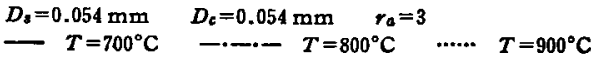

$$
\begin{aligned}
& \text { Fig. } 12 \quad \theta_{0}-D, T \& u
\end{aligned}
$$

の性質と反応速度定数との関倸を（26）式のよ5に実験 值をまとめた。また温度の影響については混合比 3，鉱 涬拈よ゙ニークス粒径がともに $0.054 \mathrm{~mm}$ の場合につい て Fig. 9 に示した。さらにこの数值を用いて反応装眉 の能力計算に必要となる. $\theta_{0}$ (球形団鉱が塩菜気流中で反 応を完結するに必要な時間）を計算した。的が求められ ると固定層，移動層，流動層を用いた反応装置について その生産能力, 運転の最適条件, 塩素の利用率などが容 易に理論的に計算できる。これについては後に報告する 予定である。

付 記：本実験を行うにあたり東大化学工学教室乙竹 直氏蛙よび徳山ッーダ株式会社高楖用氏に長期に亘 り御指導衔援助をいたたいたことを深謝いたしま す。

\section{Nomenclature}

$A$ : sectional area of the sample $\quad\left[\mathrm{cm}^{2}\right]$

$A_{0}$ : total surface area of coke-particles in the reaction-zone $\left[\mathrm{cm}^{2}\right]$

$A_{\mathrm{q}}$ : total surface area of slag-particles in the reaction-zone $\left[\mathrm{cm}^{2}\right]$

$b$ : proportional constant $[\mathrm{g} / \mathrm{cm}]$

$C_{1}$ : concentration of $\mathrm{Cl}_{2}$ in the main gas stream $\left[\mathrm{g} / \mathrm{cm}^{8}\right]$ 
$C_{1}^{\prime}$ : concentration of $\mathrm{Cl}_{2}$ at the surface of the tabletted sample $\quad\left[\mathrm{g} / \mathrm{cm}^{3}\right]$

$C_{8}$ : concentration of $\mathrm{Cl}_{2}$ at the surface of reaction $\left[\mathrm{g} / \mathrm{cm}^{3}\right]$

$C^{*}$ : equilibrium concentration of $\mathrm{Cl}_{2} \quad\left[\mathrm{~g} / \mathrm{cm}^{3}\right]$

$D$ : diameter of a spherically formed sample composed of coke and slag [cm]

$D_{p}$. diameter of a particle [mm]

$D_{\varepsilon}$ : diameter of a coke-particle [mm]

$D_{s}$ : diameter of a slag-particle [mm]

$D_{p m}$ : diameter of the smaller particle [mm]

$D_{v f}$ : diffusion coefficient in the gas $\left[\mathrm{cm}^{2} / \mathrm{sec}\right]$

$D_{v 8}$ : diffusion coefficient in the ash $\left[\mathrm{cm}^{2} / \mathrm{sec}\right]$

$E_{A}$ : activation energy [kcal/mole]

$k_{f}$ : mass transfer coefficient in the gas film $[\mathrm{cm} / \mathrm{sec}]$

$l$ : length of cylindrically formd samples

[mm]

$m$ : weight of chlorine

[g]

$M$ : molecular weight

[g/mole $]$

$P$ : total pressure

[atm]

$r$ : mixing ratio of coke and slag

[-]

$t:$ time

[sec]

$T:$ temperature

$\left[{ }^{\circ} \mathrm{K}\right]$

$u$ : velocity of $\mathbf{C l}_{2}$ gas

$[\mathrm{cm} / \mathrm{sec}]$

$V$ : molecular volume
$W:$ weight loss of the sample

$x$ : thickness of the ash [cm]

$X: \frac{\text { total weight loss of the sample }}{\text { weight of the sample before reaction }}$ $[-]$

$y$ : mole fraction of a component

$\alpha^{\prime}$ : volume of the spherically formed sample which reacts with $1 \mathrm{~g}$ of $\mathrm{Cl}_{2}\left[\mathrm{~cm}^{3} / \mathrm{g}\right]$

$\rho$ : density of gas $\left[\mathrm{g} / \mathrm{cm}^{3}\right]$

$\rho_{c}:$ density of coke $\left[\mathrm{g} / \mathrm{cm}^{3}\right]$

$\rho_{s}$ : density of slag $\left[\mathrm{g} / \mathrm{cm}^{3}\right]$

$\mu$ : viscosity of gas $[\mathrm{g} / \mathrm{cm} \cdot \mathrm{sec}]$

$\xi_{f}$ : mole fraction of inert gas [-]

$\varepsilon: \frac{\text { passing area of } \mathrm{Cl}_{2} \text { in the sample }}{\text { sectional area of the sample }} \quad[-]$

$\theta_{0}:$ time required for the complate reaction of a spherically formed sample with $\mathrm{Cl}_{2}$ [sec]

\section{Literatures cited :}

1) Yagi \& Kunii : Jour. Chem. Soc. (Japan); Ind. Chem. Soc., Vol. 56, 131 (1953)

2) Gilliland: Ind. Eng. Chem., 26, 681 (1934)

3) Wilke: Chem. Eng. Prog., 46, 95 (1950)

4) Pohlhausen: $Z$. angew. Math. Mech,, 1, 252 (1921)

5) Froessling: Gerlands Betr. Geophys., 32, 170 (1938)

6) Ranz \& Marshall : Chem. Eng. Prog., 48, 141 (1952)

7) D. Kunii : Thesie of Ph. D. "The study on the apprratus of the reaction between solids and gas." 1958

8) Yagi et, al. : Annual Report of the Engineering Research Institute. (univ. Tokyo) No. 2 (1959)

\title{
A Study of the Chlorination Velocity of Titan Slag
}

\author{
Sakae Yagi,* Daizo Kunii,* \\ Takashi Yoshioka** \& Hidemi Umeyama**
}

In order to design an apparatus for chlorinating titan slag, we must be informed of the following three fundamental data:-the reaction velocity constant $\left(\gamma k_{e}\right)$, the diffusion constant $\left(D_{v s}\right)$ of $\mathbf{C l}_{2}$ in the ash, and mass transfer coefficient $\left(k_{f}\right)$ of $\mathrm{Cl}_{2}$ in the gas film on the spherically formed sample, composed of coke and slag.

During the chlorination of the titan slag at high temperature, the weight loss of the tabletted cylindrical solid sample, composed of coke and slag, was measured by means of a thermobalance. In these experiments, variables of reaction conditions were found to be temperature, velocity of $\mathrm{Cl}_{2}$ gas, mixing ratio of coke and slag and diameter of coke particles and slag particles.

From these experimental results, we can calculate the above mentioned three fundamental data $\left(r k_{c}, D_{v s}, k_{f}\right)$.

In the first place, $\frac{d W}{d t}$ and $W$ can be known from the weight loss of the sampl a and the time of

* University of Tokyo, Department of Chemical Engineering

** Tokuyama-Soda Co., Ltd. 
reaction $t . \quad \alpha$ and $\beta$ can be obtained by means of Eq. 7, and $D_{v s}$ and $\left(\frac{1}{k_{f}}+\frac{1}{r k_{\mathrm{c}}}\right)$ by means Eqs. 8, 9 and 10.

To know $r k_{c}, k_{f}$ should be calculated independently of $r k_{c}$. In order to obtain the value of $k_{f}$, the modified equation for the mass transfer in a single sphere reported by Frosessling (Eq. i9) can be resorted to.

The three fundamental data thus obtained are given in the form of Eqs. 26, 16 and 19. Much useful information for the practical design and operation of an apparatus may be got by their application.

(1) The time required for the complete reaction of a spherically formed sample composed of coke and slag with $\mathrm{Cl}_{2} \cdots \cdots \boldsymbol{\theta}_{0}$ (Eq. 28 and 27).

(2) The capacity of the apparatus.

(3) The utility of $\mathrm{Cl}_{2}$ in the fixed-bed type appratus.

In this report calculated value of $\theta_{0}$ is employed.

\section{技術財産か、スクラップか}

「会社の研究には化工誌の技術報告に投稿

したら恰好のものがすいらんあるでしょう

ね。」

「そちですね光・.」

「ニニット・オペレーションのスケール・

フップとか,プロセス・デザインに欲しいデ

一タが豊富にあるんでしょらね。」

「そうです柿え…」

「でも会社の秘密でしょらからなかなか 外部には発表できないでしょ5ね。おしいる んですなあ」

「ええまあねえ….」

判ったよらな判らないような会話がよくと りかわされる。

確かに会社では必要とあれば多額の資金と 人村を投入して，大学の研究とは比較になら ない規模で、はなばなしく研究はスタートさ れ展開されてゆく。

しかし 5 まく有終の美をかさり，企業化さ れる研究はむしろ少ない。不運にす会社的成 果のあがらなかった研究の跡始末はどうなっ ているのだう。パイロット・プラントばか りでなく，研究の結果とのむのも整理されな いで,スクラップ化してしま5のではなかろ
5 מ。

会社が企業化，工業化の価値を诚み得なか った研究といえども，その結果を整理し，デ 一タの相関関係を導き出し，総括的な研究報 告を作製する最後の努力をはらったらとうた ろう。目先の目的に対しては効果は少なくと も長年月のそれらの䔲積こそは，その会社の 立派な得がたい技術剘産になるのではなかる 加。

あるいは失敗研究は生のデータを適当な大 学の研究室にどんどん寄付したらどうか。大 学への寄付は研究資金と決めてかかる必要は ない。ちょうど自分の死挠の遗体を解剖研究 のために奇付するよ5な考方をすればよい。 そこでは快刀乱麻を断つごとくデータは解析 され，相関関俰が求められ，5まい整理方法 がえられて，新しい価值が附与される場合が 多いのではないか。大学の研究室としても規 模の大きい実釱のデータにより自らの実験式 の適虑の笭囲の拡大の可能性をチェックする ことができることになる。

とにかく一工夫して，会社の研究をスクラ ッブ化しないで，技術財産にしたいるのであ る。 